\title{
BDNF Enhances the Differentiation but Not the Survival of CNS Stem Cell-Derived Neuronal Precursors
}

\author{
Shireen Ahmed, Brent A. Reynolds, ${ }^{a}$ and Samuel Weiss \\ Neuroscience Research Group, Departments of Anatomy and Pharmacology and Therapeutics, and Graduate \\ Department of Neuroscience, University of Calgary Faculty of Medicine, Calgary, Alberta, Canada T2N 4N1
}

\begin{abstract}
We have previously reported the isolation of an EGF-responsive precursor from the embryonic and adult mouse striatum. This precursor exhibits self renewal and the ability to produce a sphere of undifferentiated cells which can be induced to differentiate into neurons and glia. RT-PCR analysls of these spheres of undifferentlated cells revealed the expression of mRNA for the trkB neurotrophin receptor, both with and without the catalytic domain, and little or no expression of trkA or trkC. We examined the actions of BDNF on the fate of EGF-generated neural precursors. Ten days after a one-time exposure to BDNF, single EGF-generated spheres showed a twofold increase in neuron number and a marked enhancement in neurite outgrowth. Examination of neuronal nuclei with immunochemical probes for $\mathrm{c}$-fos and bromodeoxyuridine revealed that the actions of BDNF were directly upon neuronal cells and did not involve division of neuronal precursors. The twofold increase in neuronal number due to BDNF, observed after 10 $\mathrm{d}$ in vitro, was significantly reduced after $21 \mathrm{~d}$ in vitro and was not apparent at $\mathbf{2 7} \mathrm{d}$ in vitro. Quantitative analyses revealed that while repeated application of BDNF did not prevent the loss of neuron number over time, it did result in a significant increase in neurite numbers. Moreover, delayed addition of BDNF mimicked the increase in neuronal numbers seen when BDNF was present throughout. These BDNF actions did not appear to involve the enhancement of a novel neuronal phenotype, with all effects being due to increase in the numbers and neurite outgrowth of neurons that colocalize GABA and substance $P$. These findings suggest that BDNF markedly enhances the antigenic and morphologic differentiation of EGF-generated neuronal precursors. BDNF alone does not appear to act as a survival factor for neuronal precursors nor is it sufficient for preventing their death over time.
\end{abstract}

\footnotetext{
Received Feb. 6, 1995; revised Apr. 14, 1995; accepted Apr. 19, 1995.

We thank Dr. Mariano Barbacid, Bristol-Myers Squibb, for generously donating the BDNF used in this study, Drs. Mark Brown and Mayi ArcellanoPanlilio for assistance in molecular probing for trk receptors, and Dr. Joseph Hammang for advice during early stages of this study. We are indebted to Drs. R. B. Campenot and A. G. M. Bulloch for critical reading of an earlier version of the manuscript. This work was supported by the Medical Research Council of Canada (MRC). S.W. is an Alberta Heritage Foundation for Medical Research Scholar and an MRC Scientist.

Correspondence should be addressed to Samuel Weiss, Neuroscience Research Group, Departments of Anatomy and Pharmacology and Therapeutics, and Graduatc Department of Ncuroscicnce, University of Calgary Faculty of Medicine, 3330 Hospital Drive N.W., Calgary, Alberta, Canada T2N 4N1.

aPresent address: NeuroSpheres Ltd., 83 HM, 3330 Hospital Drive N.W., Calgary, Alberta T2N $4 \mathrm{~N} 1$.

Copyright (C) 1995 Society for Neuroscience $0270-6474 / 95 / 155765-14 \$ 05.00 / 0$
}

[Key words: brain-derived neurotrophic factor, trkB, stem cells, neuronal precursors, neuronal differentiation, neurite outgrowth]

Cellular diversity in the mammalian CNS is generated from a small number of precursor cells in the neural ectoderm. While the existence of multipotent precursors for neurons and glia has been described both in vitro (Raff, 1989; Temple, 1989; Williams et al., 1991; Kilpatrick and Bartlett, 1993) and in vivo (Turner and Cepko, 1987; Frederiksen and McKay, 1988; Galileo et al., 1990), the signals that regulate their proliferation, differentiation and subsequent survival are less well understood. The neurotrophins, a family of epigenetic factors that influence neural development, include NGF, brain-derived neurotrophic factor (BDNF), neurotrophin-3 (NT-3), neurotrophin-4/5 (NT-4/ 5), and neurotrophin 6 (NT-6) (Leibrock et al., 1989; Hohn et al., 1990; Maisonpierre et al., 1990; Berkemeier et al., 1991; Hallbook et al., 1991; Gotz et al., 1994). These factors are small proteins, which share at least $50 \%$ sequence homology, regulate proliferation of neuronal precursors, and enhance the survival and differentiation of postmitotic neurons (reviewed in Davies, 1994). Signal transducing receptors for neurotrophins, collectively referred to as $t r k \mathrm{~s}$, are also a structurally related group of proteins (Chao, 1992; Barbacid, 1994). These receptors fall into a family of protein tyrosine kinase receptors, consisting of an extracellular binding domain, a transmembrane region and an intracellular catalytic kinase domain (Klein et al., 1989; Lamballe et al., 1991). Although each receptor exhibits high affinity binding of its respective ligand, for example trkB encodes a functional receptor for BDNF (Klein et al., 1991; Soppet et al., 1991; Squinto et al., 1991), multiple interactions exist between the trks and the neurotrophins (reviewed in Barbacid, 1994). The spatiotemporal expression of the different neurotrophins and their receptors, in the embryo and the adult CNS, suggests that these molecules play specific roles throughout development.

Consistent with the widespread distribution of $t r k \mathrm{~B}$ in the PNS and CNS (Klein et al., 1990), BDNF has been reported to have survival and/or differentiation actions on a number of ncuronal populations in vitro. BDNF promotes survival and neurite outgrowth of cultured neural crest-derived and placode-derived sensory neurons and parasympathetic nodose ganglion neurons (Lindsay et al., 1985; Davies et al., 1986) but not sympathetic neurons (Lindsay and Rohrer, 1985). In the CNS, BDNF supports the survival and phenotypic differentiation of basal forebrain cholinergic neurons (Alderson et al., 1990; Knusel et al., 1991) and enhances the survival of cultured dopaminergic neurons (Hyman et al., 1991, 1994; Knusel et al., 1991), cerebellar granule cells (Segal et al., 1992; Lindholm et al., 1993), retinal 
ganglion cells (Johnson et al,, 1986; Rodriguez-Tebar et al,, 1989) and motor neurons (Wong et al., 1993). In addition to promoting survival, BDNF also regulates the expression of phenotypic markers of cultured GABAergic neurons of the developing ventral mesencephalon and striatum (Knusel et al., 1991; Ventimiglia et al., 1993; Hyman et al., 1994) and that of calbindin-containing neurons of striatum and the hippocampus (Collazo et al., 1992; Ventimiglia et al., 1993). Recent findings indicate that BDNF is able to elevate cellular GABA content of cultured striatal neurons (Mizuno et al., 1994) and increase the numbers of neurons expressing calbindin or AChE (Ip et al., 1993), without affecting the survival of these cells. Thus, although considerable evidence has accumulated, suggesting a role for $\mathrm{BDNF}$ in the development of central neurons, its precise action, for example, survival versus differentiation, remains unclear.

We have reported the isolation, from the embryonic and adult mouse striatum, of an epidermal growth factor (EGF)-responsive CNS precursor cell (Reynolds and Weiss, 1992; Reynolds et al., 1992) that exhibits self renewal and the ability to generate neurons and glia. These in vitro properties and the ability to participate in repopulation in the adult CNS in vivo (Morshead et al., 1994), suggest that this EGF-responsive precursor is a stem cell. These stem cells proliferate in response to EGF and form clusters (spheres), which lift off the substrate and float in suspension where they continue to proliferate. At 6-7 d in vitro (DIV), the majority of the cells within these spheres express immunoreactivity for nestin, an intermediate filament found in undifferentiated cells of the CNS, but they do not express any of the antigens characteristic of mature CNS cells. Clonal analysis of individual cells within the EGF-generated spheres reveals that some of the cells produced can generate new spheres (Reynolds and Weiss, unpublished observations), while others respond to other mitogens, such as basic fibroblast growth factor (bFGF) and undergo limited proliferation to generate neurons and glia (Vescovi et al., 1993). In the latter study, while bFGF was able to induce the proliferation of neuronal progenitor cells, these cells required additional factors for their terminal differentiation. In order to further our understanding of the steps between stem cell proliferation and the production and phenotypic determination of neurons, we asked whether the stem cell progeny expressed any of the $t r k$ receptors. Identification of the $t r k \mathrm{~B}$ receptor on these cells prompted us to examine the actions of BDNF on EGF-generated neuronal precursors. Our results suggest that BDNF acts as a differentiation factor for neuronal precursors arising from the EGF-responsive stem cell. In addition, our findings argue against BDNF being sufficient to ensure the long term survival of these newly generated neurons.

\section{Materials and Methods}

Primary cell culture. Striata were removed from $14 \mathrm{~d}$ old CD1 albino mouse embryos (Charles River) and mechanically dissociated in culture media with a fire-narrowed Pasteur pipette. The culture media was composed of DMEM/F12 (1:1) (GIBCO), glucose $(0.6 \%)$, glutamine (2 $\mathrm{mM})$, sodium bicarbonate ( $3 \mathrm{~mm})$, and HEPES buffer. A bormone and salt mixture including insulin $(25 \mu \mathrm{g} / \mathrm{ml})$, transferrin $(100 \mu \mathrm{g} / \mathrm{ml})$, progesterone $(20 \mathrm{nM})$, putrescine $(60 \mathrm{nM})$, and selenium chloride $(30 \mathrm{nM})$ was used as supplement (all from Sigma except glutamine; GIBCO). Cells were plated at a density of 200,000 cells/ml in Corning T75 (GIB$\mathrm{CO} / \mathrm{BRL}$ ) culture flasks in the above media in the presence of $20 \mathrm{ng} /$ ml EGF (purified from mouse submaxillary; Collaborative Research). After 6 DIV, floating clusters of cells (spheres) were centrifuged (400 $\mathrm{rpm}$ ) and the EGF-containing media removed. The pellet was mechanically dissociated and reseeded in fresh EGF-containing media at 50,000 cells/ml, until secondary spheres were generated. All spheres used for examining the actions of BDNF were passaged at least once.

Reverse transcription, $P C R$, and sequencing for trks. Total RNA from EGF-generated spheres was prepared utilizing the single-phase phenol: guanidine isothiocyanate reagent Trizol according to manufacturer's instructions (BRL). Cells were pelleted at $500 \times g$ and lysed directly in the reagent $\left(0.2 \mathrm{ml} / 10^{6}\right.$ cells $)$. The organic and aqueous phases were separated by addition of 0.2 volumes of chloroform and centrifugation at $3500 \times g$. Total RNA was precipitated from the aqueous phase with addition of an equal volume of isopropanol and incubation at $-20^{\circ} \mathrm{C}$ overnight. The RNA pellet was redissolved in water and RNA concentration was determined by absorbance at $260 \mathrm{~nm}$. The RNA was repelleted with addition of 2 volumes ethanol/50 $\mathrm{mM} \mathrm{NH}_{4} \mathrm{Ac}$, followed by overnight incubation at $-20^{\circ} \mathrm{C}$ and resuspended in water for direct use in reverse transcriptase reactions. First strand cDNA was made utilizing Superscript reverse transcriptase following the method as outlined by the manufacturer (BRL). Briefly, $1 \mu \mathrm{g}$ of total RNA and $0.5 \mu \mathrm{g}$ oligo dT was heated to $65^{\circ} \mathrm{C}$ in $12 \mu \mathrm{l}$ of $\mathrm{H}_{2} \mathrm{O}$ and quickly chilled on ice. The annealed mRNA:oligo dT complexes were incubated at $42^{\circ} \mathrm{C}$ for $2.5 \mathrm{hr}$ with $200 \mathrm{U}$ of reverse transcriptase in $20 \mu \mathrm{l}$ total volume of $0.5 \mathrm{~mm}$ dNTPs; $50 \mathrm{mM}$ Tris $\mathrm{pH} 8.3 ; 75 \mathrm{mM} \mathrm{KCl} ; 3 \mathrm{mM} \mathrm{MgCl}$, and $10 \mathrm{~mm}$ DTT. The reaction mix was heat inactivated $\left(65^{\circ} \mathrm{C}\right.$ for $\left.15 \mathrm{~min}\right)$ and diluted to $100 \mu \mathrm{l}$ with $\mathrm{H}_{2} \mathrm{O}$. The diluted reaction mix was used directly in PCR reactions. Primers specific for individual members of the trk receptor family were designed from published sequence data as follows: (1) trkA, accession \#M85214 (Rattus rattus), trkA(2253) $=5^{\prime}$-ggtaccagctctccaacactgagg- $3^{\prime}$, trkA $(2456 \mathrm{c})=5^{\prime}$-ccagaacgtccaggtaactcggtg- $3^{\prime}$, $204 \mathrm{bp}$ amplified product; (2) trk B full length catalytic form, accession \#X17647 (Mus spretus), trkB +kd(1806) = 5'-tctatgccgtggtggtgattgc-3', $\operatorname{trk\mathrm {B}}+\mathrm{kd}(2228 \mathrm{c})=5^{\prime}$-gcgtcttcacagccaccaggat $-3^{\prime}, 423 \mathrm{bp}$ amplified product; (3) trk B truncated noncatalytic form, accession \#M33385 (Mus musculus), trkB-kd(1745) $=5^{\prime}$-aagcgagctgttgactatacg-3', trkB$\mathrm{kd}(2145 \mathrm{c})=5^{\prime}$-gtgcacttagacctagctatgactt-3', $397 \mathrm{bp}$ amplified product; (4) trk C, accession \#L14447 (Rattus norvegicus), $\operatorname{trkC}(2384)=5^{\prime}$ catggttccagctctctaacacag- $3^{\prime}, \operatorname{trkC}(2606 \mathrm{c})=5^{\prime}$-accagtcaccactagccaagaatg-3', 223 bp amplified product; (5) beta-actin, accession \#X03672 (Mus musculus), actin(182) = 5'-cgtgggccgccctaggcacca- $3^{\prime}$, actin $(424 \mathrm{c})$ $=5^{\prime}$-ttggccttagggttcagggggg-3', 243 bp amplified product. Numbers in brackets refer to the position of the primer in the nucleotide sequence, " $c$ " denotes the complimentary strand. Polymerase chain reaction analyses were performed in a final volume of $50 \mu \mathrm{l}$ containing $25 \mathrm{nmol}$ of each primer pair, $2.5 \mu \mathrm{l}$ of the reverse transcription reaction, $10 \mathrm{~mm}$ Tris- $\mathrm{HCl}, \mathrm{pH} 8.3,50 \mathrm{mM} \mathrm{KCl}, 1.5 \mathrm{mM} \mathrm{MgCl}_{2}, 200 \mu \mathrm{M}$ each of the four dNTPs and $1 \mathrm{U}$ of taq DNA polymerase (Perkin Elmer). After a denaturation step of $5 \mathrm{~min}$ at $95^{\circ} \mathrm{C}$, amplifications were carried out for 25 cycles of $94^{\circ} \mathrm{C} / 30 \mathrm{sec}, 60^{\circ} \mathrm{C} / 30 \mathrm{sec}$, and $72^{\circ} \mathrm{C} / 1 \mathrm{~min}$. Final products were analyzed on a $2 \%$ agarose/TAE gel. PCR amplification products were excised out of the agarose gel and isolated utilizing spin columns according to the manufacturcr's protocol (Qiagen). The purified fragments were sequenced directly utilizing specific primers and the dsDNA cycle sequencing system according to manufacturer's instructions (BRL).

Plating spheres to examine the actions of $B D N F$. Sterile glass coverslips in 24-well plates (Nunclon) were incubated overnight at $37^{\circ} \mathrm{C}$ in a solution of polyornithine $\left(15 \mu \mathrm{g} / \mathrm{ml}\right.$; Sigma) in dd $\mathrm{H}_{2} \mathrm{O}$. Twenty-four hours later, excess polyornithine was removed and the coverslips were rinsed three times ( $5 \mathrm{~min}$ each) with PBS. Media was added to plates and allowed to equilibrate at $37^{\circ} \mathrm{C}$. EGF-generated spheres were rinsed free of EGF by centrifuging at $400 \mathrm{rpm}$ for $5 \mathrm{~min}$, aspirating the EGFcontaining supernatant, and replacing quickly with media. Resuspended spheres were then transferred into $35 \mathrm{~mm}$ petri dishes and also allowed to equilibrate at $37^{\circ} \mathrm{C}$ before plating. Four to five individual spheres were transferred by micro manipulation onto the polyornithine coated coverslips. The spheres were cultured in $1 \mathrm{ml}$ of media containing $1 \%$ FBS (UBI, Lake Placid, NY) in the absence or presence of human recombinant BDNF (10 ng/ml) (generously supplied by Dr. M. Barbacid, Bristol Meyers Squibb, Princeton, NJ). This concentration of BDNF has been demonstrated to enhance the in vitro survival of retinal ganglion cells (Rodriguez-Tebar et al., 1989) and septal cholinergic neurons (Alderson et al., 1990), and to enhance both the survival and neurite outgrowth of cultured cerebellar granule cells (Lindholm et al., 1993). BDNF was added to the culture media only at the time of initial plating unless otherwise indicated. Spheres were cultured for different lengths of time depending on the experiment, typically 10 DIV.

Antibodies. Mouse monoclonal antibodies and rabbit polyclonal an- 
tisera directed against neuronal and glial antigens and neurotransmitter phenotypes were used as primary antibodies for indirect immunofluorescence. Polyclonal anti-neuron specific enolase (NSE) (1:1000) was kindly provided by Dr. R. Hawkes (University of Calgary, AB). Polyclonal anti-glial fibrillary acidic protein (GFAP, 1:1000) was a gift frum Dr. L. Eng (Stanford University School of Medicine, CA). Polyclonal antisera directed against substance-P (1:500), 5-HT (1:1000), met-enkephalin $(1: 1000)$, somatostatin $(1: 100)$, and neuropeptide- $Y(1: 100)$ were purchased from Incstar (Stillwater, MN). Polyclonal anti- $\gamma$-amino butyric acid (GABA, 1:5000) and monoclonal anti- $\beta$-tubulin (Type III 1:1000) were purchased from Sigma. Polyclonal antisera directed against tyrosine hydroxylase $(1: 750)$ and glutamate $(1: 5000)$ were purchased from Pel-Freez (Rogers, AR) and Arnel (New York, NY), respectively. Monoclonal antibodies against GFAP, $(1: 100)$, microtubule associated protein-2 (MAP-2, 1:400), and O4 (1:10) were obtained from Boehringer Mannheim, (Laval, Quebec). Anti-bromodeoxyuridine (BrdU, 1:5), used in proliferation assays was obtained from Amersham (Oakville, Ontario) and polyclonal antiserum to the immediate-early gene product c-fos ('IF6; 1:100), was a gift from Dr. K. Riabowal (University of Calgary, Calgary, $A B$ ).

Secondary antibodies raised in goat against mouse and rabbit immunoglobulins, conjugated to the fluorophore rhodamine isothiocyanate (RITC, 1:200) or fluorescein isothiocyanate (FITC, 1:100), were purchased from Jackson Immunochemicals (Westgrove, PA). Alkaline phosphatase conjugated goat anti-rabbit IgG (1:100) was purchased from GIBCO.

Immunocytochemistry. After the appropriate number of DIV (depending on the experiment), spheres were fixed with $4 \%$ paraformaldehyde (plus $0.1 \%$ glutaraldehyde for GABA immunostaining) for 20 $\mathrm{min}$, rinsed three times in PBS (10 min. each), and incubated with primary antibodies in PBS containing 10\% normal goat FBS for $2 \mathrm{hr}$ at $37^{\circ} \mathrm{C}$. Permeabilization for intracellular antigens was achieved by adding $0.3 \%$ Triton X-100 (BDH, Toronto, Ontario) to primary antibody solutions. For dual-labeling experiments, primary antibodies generated from different species were added together. Following incubation coverslips were rinsed three times (10 min each) with PBS and incubated in secondary antibodies for $30 \mathrm{~min}$ in the dark at room temperature. Again, for dual labeling, appropriate secondary antibodies were added together. After three final washes in PBS, coverslips were rinsed with double distilled water $\left(\mathrm{dd}_{2} \mathrm{O}\right)$ and mounted with FluorSave on glass slides. Fluorescence was detected and photographed with a Nikon Optiphot photomicroscope.

For some experiments, neuronal cell numbers were quantified by using indirect immunocytochemistry with enzyme-linked, rather than fluorescence-linked secondary antibody. The NSE antibody was recog nized by incubating the coverslips with goat anti-rabbit IgG linked to alkaline phosphatase for $30 \mathrm{~min}$ at room temperature. Staining was developed with a $0.1 \mathrm{M}$ Tris buffer $(\mathrm{pH} 9.5)$ containing $\mathrm{NaCl}(0.1 \mathrm{M})$, $\mathrm{MgCl}_{2}(5 \mathrm{mM})$, nitro blue tetrazolium (NBT) $(0.3 \mathrm{mg} / \mathrm{ml}$ ), and bromochloroindolyl phosphate (BCIP) $(0.15 \mathrm{mg} / \mathrm{ml})$. The reaction was terminated by rinsing with tap water.

Bromodeoxyuridine ( $\mathrm{Brd} U$ ) labeling and detection. To determine if cells were dividing in the absence or presence of BDNF, BrdU $(1 \mu \mathrm{M})$ was added to each of the wells containing spheres (in media with $1 \%$ FBS) at the time of plating. BrdU remained in the media for the duration of the culture. At $10 \mathrm{DIV}$, neuronal and glial proliferation was visualized by dual label immunocytochemistry for BrdU and the neuronal/glial antigens NSE, MAP-2, and GFAP. The identity of the BrdU incorporating cells was further confirmed by morphological examination.

Growth factor-induced expression of $c$-for. EGF-generated spheres were rinsed free of EGF as described above and resuspended in media containing 1\% FBS. A few of these were then transferred onto polyornithine coated glass coverslips in culture plates. At 3 DIV the spheres were exposed to EGF $(20 \mathrm{ng} / \mathrm{ml})$ or BDNF $(100 \mathrm{ng} / \mathrm{ml})$, for $30-180$ min. These coverslips were transferred into $4 \%$ paraformaldehyde for fixation, rinsed in PBS three times, and incubated for $45 \mathrm{~min}$ at $37^{\circ} \mathrm{C}$ with $c$-fos antiserum and the neuronal antigen $\beta$-tubulin or the glial antigen GFAP. Incubation in the primary antibodies, was followed by incubation in appropriate secondary antibodies and the cellular response to EGF/BDNF stimulation was examined by looking for immunoreactivity for c-fos and $\beta$-tubulin or GFAP.

Quantification of cell numbers and process outgrowth. Quantification of neuronal numbers was performed double blind, by counting neuronal cell bodies resulting from differentiation within each sphere at time intervals designated by the particular experiment. Neuronal cells were identified by morphology and their immunoreactivity for NSE, MAP-2 or $\beta$-tubulin. The numbers of neurons counted in all the experiments were pooled within each condition and divided by the total number of spheres in that procedure. The resultant mean number of neurons per sphere in each procedure was used in data illustration and analysis. For statistical analysis of the data, the dependent measure was the number of neurons per sphere and the null hypothesis was that the number of neurons per sphere in the different procedures would be the same. $\chi^{2}$ analyses were carried out to determine significance across entire experiments and to further determine which difference between procedures were significant. Levels of significance were $p<0.05, p<0.01$, and $p<0.001$.

Quantification of process outgrowth (in Table 1) was achieved by preparing composites of five spheres in each of the six procedures described. Process outgrowth was quantified 21 DIV and in a manner such that the reader was blind to experimental procedures. Data on process outgrowth was obtained from the same experiments that were carried out for the quantification of neuronal numbers in the previous section Histochemical immunostaining for NSE was utilized. Photographing consecutive fields of view at high magnification, allowed for resolution sufficient for the quantification of processes extending out from cells around the core of the sphere. The number of neurite intersections at a circle drawn a constant distance of $120 \mu \mathrm{m}$ from the center of the sphere for each sphere were counted.

\section{Results}

Cells within the EGF-generated spheres express trkB

Reverse transcription-PCR analysis was used to examine the mRNA expression of the $t r k$ receptor family in EGF-generated spheres of undifferentiated cells. PCR primer pairs specific for beta-actin, $\operatorname{trkA}$, the catalytic and noncatalytic forms of $t r k \mathrm{~B}$, and $t r k \mathrm{C}$ were designed from published sequence data and a representative RT-PCR experiment is illustrated in Figure 1. mRNA transcripts for the full-length catalytic and truncated noncatalytic forms of $t r k B$ were readily detected after 25 cycles of PCR. This result was confirmed in two additional, independent RT-PCR experiments with newly isolated mRNA from EGFgencrated spheres. While the expression of trkA and trkC mRNA is not readily detected in EGF-generated spheres, trace amounts of trkA and trkC amplified products could be seen if the PCR reactions were driven past 40 cycles (data not shown). The identity of the specific amplified fragments were confirmed by double-strand cycle sequencing with taq polymerase. These data suggest that the catalytic and non-catalytic isoforms of $t r k \mathrm{~B}$ are the only members of the neurotrophin receptor fanily that are transcribed in robust levels in cells within the EGF-generated spheres

\section{Neuronal cells within the EGF-generated spheres respond to $B D N F$}

The actions of BDNF on EGF-generated spheres was examined by plating spheres on coverslips, rinsed free of EGF and in the presence of $1 \%$ fetal bovine serum (FBS), followed by indirect immunocytochemistry after various periods in vitro. When examined after $10 \mathrm{~d}$ in vitro (DIV), both in the absence or presence of BDNF, neurons were identified by their morphologic and antigenic properties (Fig. 2). These neuronal cells possessed relatively small round or pyramidal cell bodies with thin processes. Dual label immunocytochemistry demonstrated that cells with these morphological characteristics expressed the antigens neuron-specific enolase (NSE) and microtubule associated protein-2 (MAP-2) (Fig. 2A,B), as well as $\beta$-tubulin (Type III) and the neurotransmitter GABA (Fig. $2 C, D$ ). The glial cells within the spheres, astrocytes and oligodendrocytes, were identified by the expression of GFAP and $\mathrm{O} 4$ immunoreactivities, respectively (data not shown). 
Figure 1. PCR amplifications of neurotrophin receptor mRNA in EGF-generated spheres of undifferentiated cells. First strand cDNA from EGF-generated spheres of undifferentiated cells was amplified utilizing neurotrophin receptor specific primer sets as described in Materials and Methods. $\mathrm{Mr}, 100 \mathrm{bp}$ ladder (BRL); Act, $\beta$-actin; trkB +, full length $\operatorname{trk\mathrm {B}}$ containing the catalytic kinase domain; trkB-, truncated trkB lacking the cytoplasmic kinase domain. The subscript $\mathrm{c}$ denotes negative control reaction lacking the RT product. Amplified products were run out on a $2 \%$ agarose/TAE gel and visualized with ethidium bromide. The figure is printed in reverse contrast for clarity.

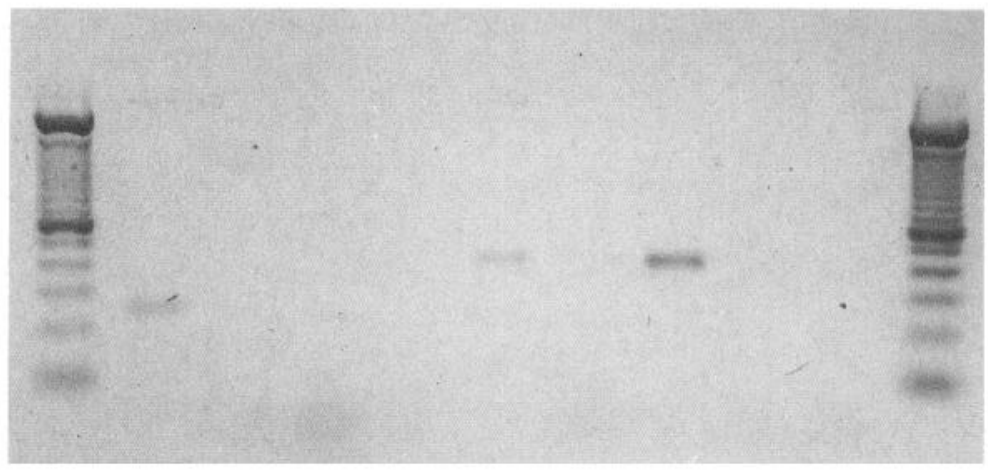

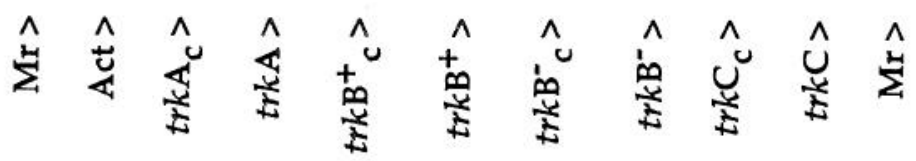

In order to determine the phenotype of the cells responding to BDNF, we examined the expression of c-fos protein (Greenberg et al., 1985; Curran and Morgan, 1991) in cells within the EGF-generated spheres. In preliminary experiments (data not shown), spheres were rinsed free of EGF, cultured in media containing $1 \%$ FBS for 3 DIV, and reexposed to EGF for 30,60 , 90,120 , or $180 \mathrm{~min}$. We expected EGF to induce expression in a large proportion of the cells and this would be useful as a validation of the assay and a reference to which the BDNF response could be compared. Immunoreactivity to c-fos was detected in cells within spheres exposed to EGF for $30 \mathrm{~min}$ but cellular nuclei were most intensely and clearly labeled after a $60 \mathrm{~min}$ exposure. By $120 \mathrm{~min}$ diffuse c-fos staining was observed throughout the cell and with no nuclear specificity. When spheres had been exposed to EGF for $180 \mathrm{~min}$, as was the case in the absence of added growth factors, little or no c-fos ex-
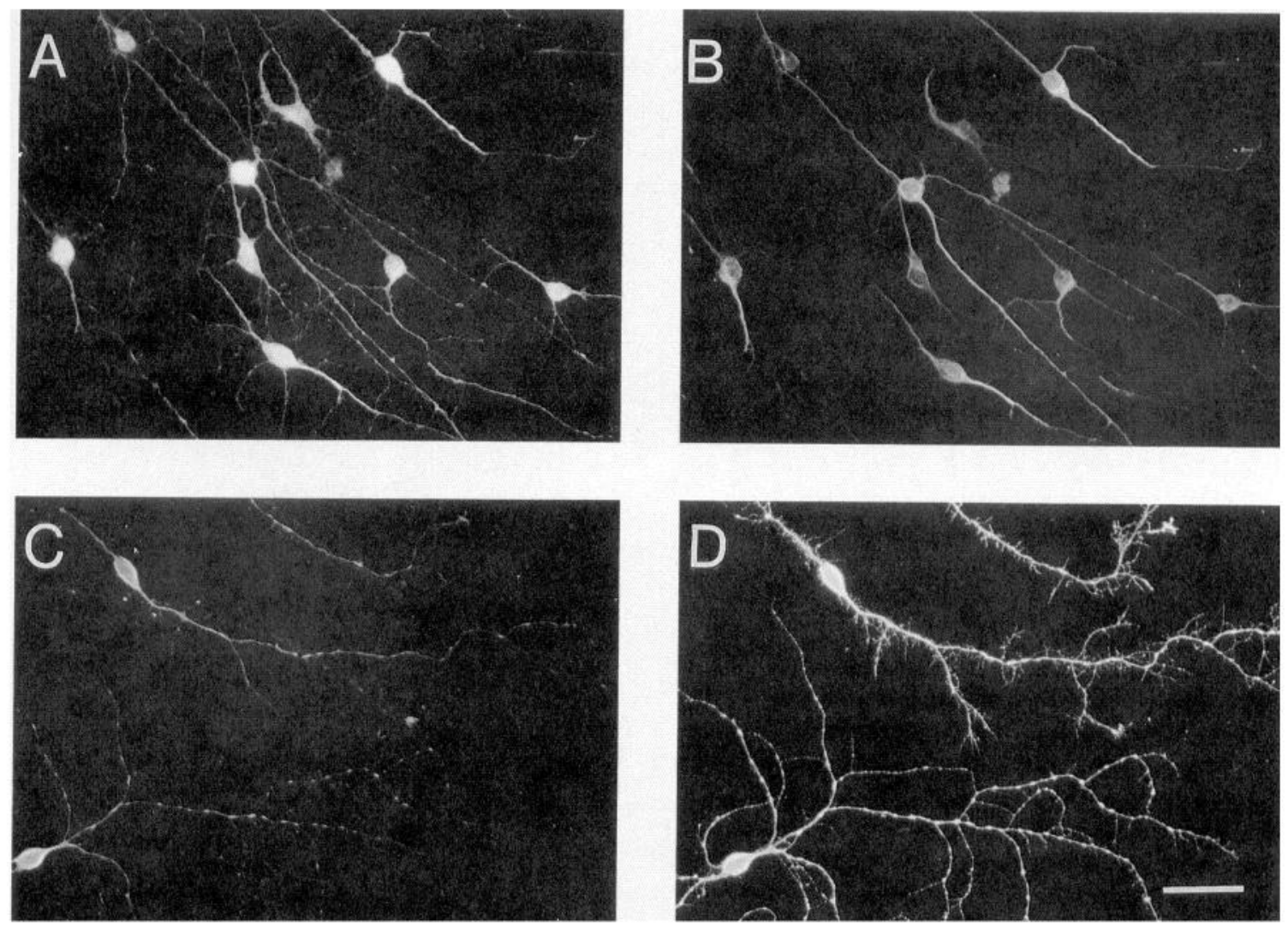

Figure 2. Morphologic and antigenic properties of neurons derived from EGF-generated spheres of undifferentiated cells. Dual label indirect immunocytochemistry of cells within spheres cultured in the presence of $10 \mathrm{ng} / \mathrm{ml}$ BDNF for 10 DIV. Cells with neuronal morphology exhibited relatively small, round or pyramidal cell bodies with long, thin processes extending out. These cells exhibit dual immunoreactivity for NSE ( $A$ ) and MAP-2 $(B)$, as well as $\beta$-tubulin $(C)$ and GABA $(D)$. Scale bar, $30 \mu \mathrm{m}$. 

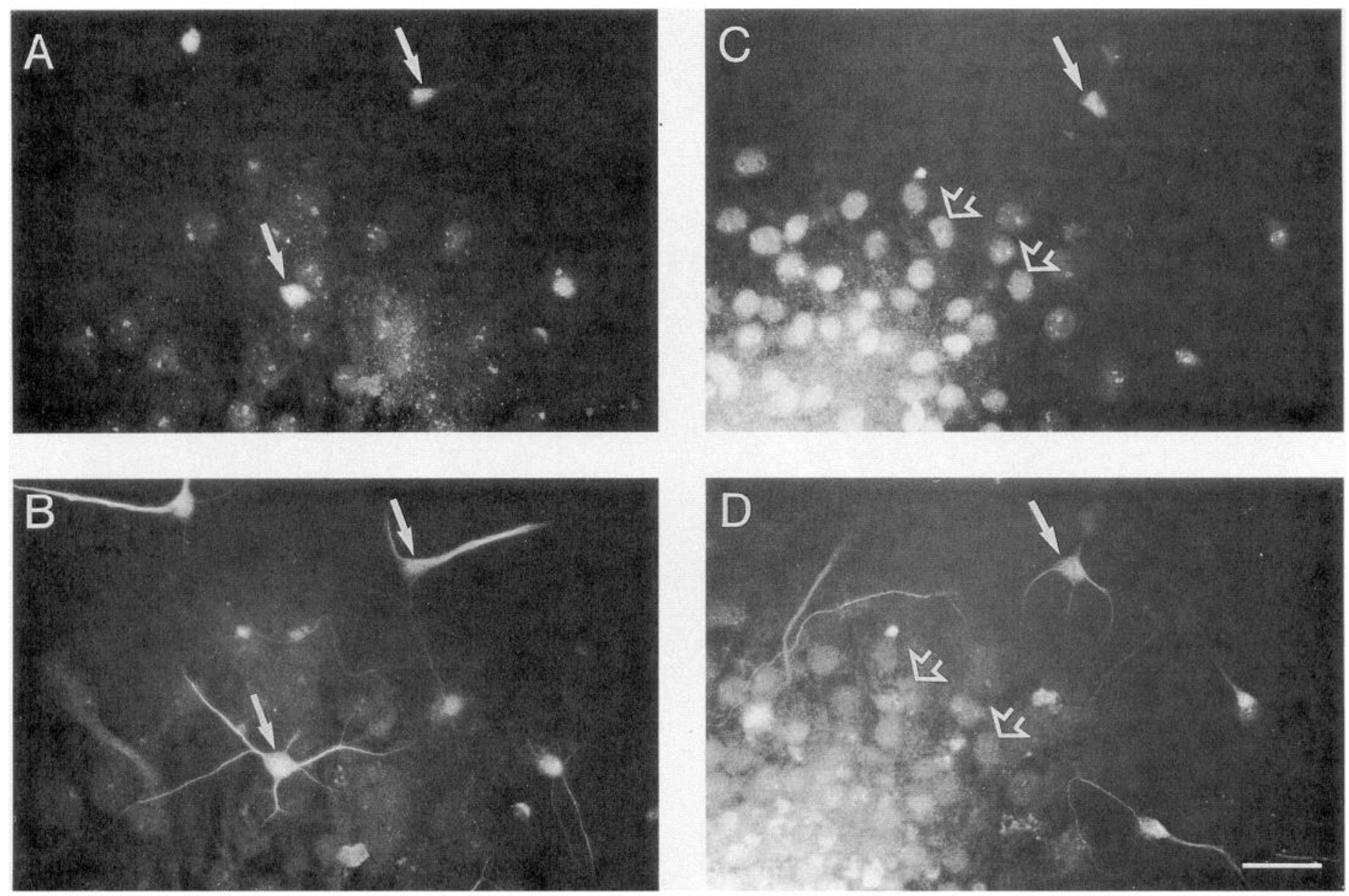

Figure 3. Cellular targets for BDNF and EGF in 3 DIV spheres of cells. EGF-generated spheres, that were rinsed free of EGF and cultured in the absence of additional growth factors for 3 DIV, were exposed to BDNF or EGF for $60 \mathrm{~min}$. Spheres were immediately fixed and subsequently processed for dual label immunocytochemistry for $\mathrm{c}$-fos $(A, C)$ and the neuronal antigen $\beta$-tubulin $(B, D)$. When spheres were exposed to BDNF, c-fos immunoreactivity ( $A$, arrows) was restricted to $\beta$-tubulin-immunoreactive $(B$, arrows) cells. Under the same experimental conditions, when spheres were exposed to EGF, c-fos immunoreactivity $(C)$ was found in both non-neuronal (short, open arrows) and $\beta$-tubulin-immunoreactive $(D$, arrow) cells. Scale bar, $30 \mu \mathrm{m}$.

pression was observed. We then examined and compared c-fos expression in 3 DIV spheres exposed to BDNF $(100 \mathrm{ng} / \mathrm{ml}$; Collazo et al., 1992) or EGF (20 ng/ml) for $60 \mathrm{~min}$ (Fig. 3). We performed dual label immunocytochemistry with c-fos antiserum and $\beta$-tubulin antibody, the latter chosen for its characteristic as an early neuronal marker (Lee et al., 1990). In spheres exposed to BDNF, c-fos expression was restricted to a subpopulation of cells (Fig. $3 A$ ) that colocalized $\beta$-tubulin (Fig. $3 B$ ) and exhibited an immature neuronal morphology. These findings were observed in three independent culture preparations. In contrast, spheres exposed to EGF showed c-fos expression in many cells (Fig. $3 C$ ), a small proportion of which colocalized $\beta$-tubulin (Fig. 3D). Many of the cells that expressed c-fos in response to EGF were astrocytes (data not shown), while other responding cells expressed no antigens characteristic of differentiated cells. These results suggested that BDNF actions were restricted to and directly on neuronal cells within the EGF-generated spheres.

\section{$B D N F$ increases the numbers of neurons and promotes} process growth

EGF-generated spheres were rinsed free of EGF and cultured on glass coverslips in media containing $1 \%$ FBS in the absence or presence of BDNF $(10 \mathrm{ng} / \mathrm{ml})$. We previously determined that the inclusion of $1 \%$ FBS was necessary to ensure viability of EGF-generated precursor cells following removal of EGF (data not shown). The concentration of BDNF used has been demonstrated to enhance the in vitro survival of retinal ganglion cells (Rodriguez-Tebar et al., 1989) and septal cholinergic neurons (Alderson et al., 1990), and to enhance both the survival and neurite outgrowth of cultured cerebellar granule cells (Lindholm et al., 1993). Within 7 DIV, a difference was observed between BDNF-treated versus control spheres. Cells with neuronal morphology appeared in greater numbers, had migrated from the core of the spheres and exhibited extensive branching. This phenomenon was fully developed after 10 DIV and could be seen after fixing the spheres and immunostaining for GABA (Fig. 4). In control spheres, most neurons remained associated with the underlying glial bed and oriented neurites away from the core of the sphere (Fig. 4A). In spheres exposed to BDNF (Fig. 4B), many more neurons were observed, some remained within the core of the sphere while others migrated up to $100 \mu \mathrm{m}$ away, and all of them exhibited extensive neuritic branching. Quantitative analyses of NSE/MAP-2 double-labeled cells with neuronal morphology showed a twofold increase $(p<0.001)$ in 

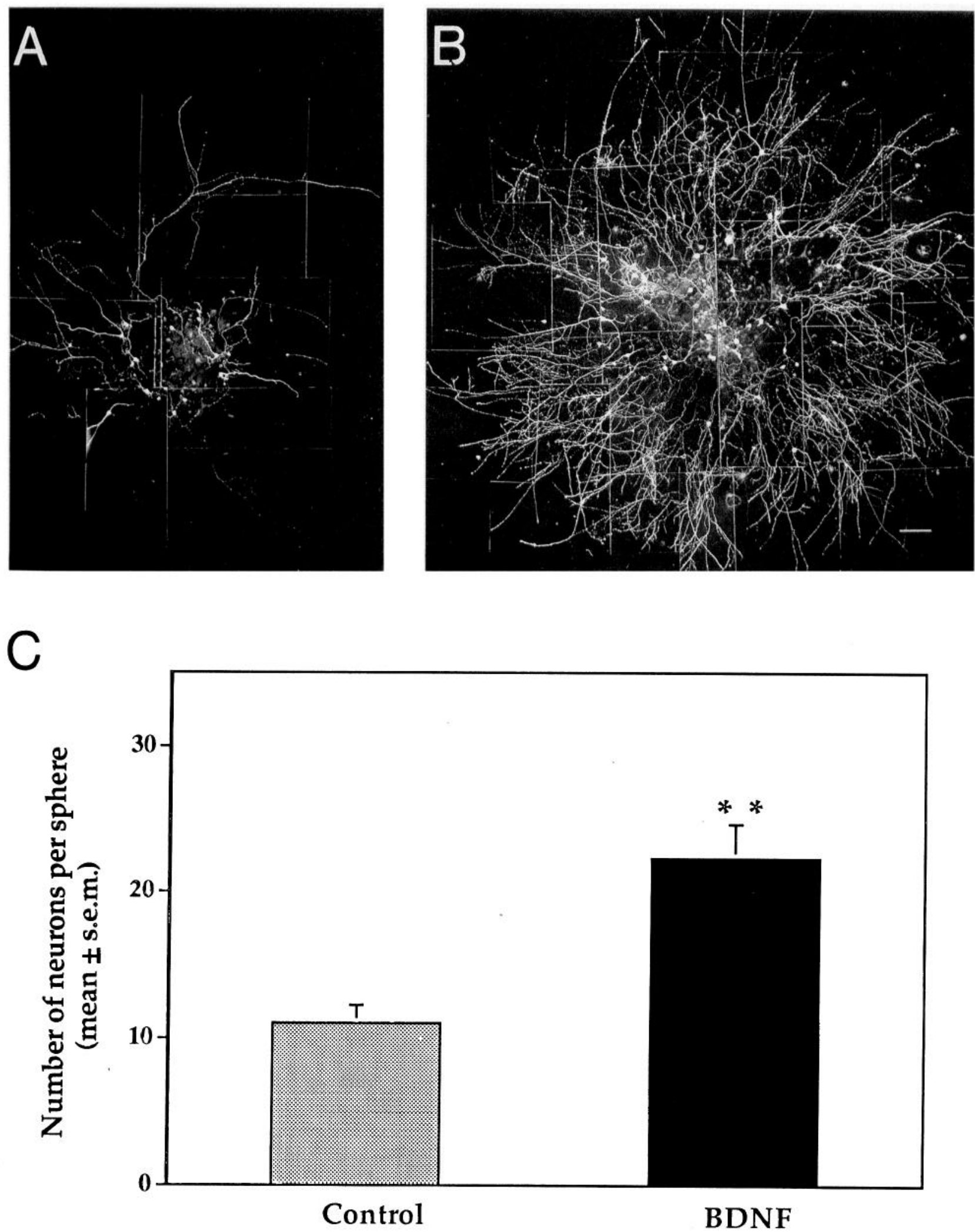

Figure 4. BDNF increases the numbers of neurons within EGF-generated spheres and enhances neuronal process growth. EGF-generated spheres that were rinsed free of EGF and cultured in the absence $(A)$ or presence $(B)$ of $10 \mathrm{ng} / \mathrm{ml}$ of BDNF for 10 DIV, were fixed and processed for indirect immunocytochemistry with antiserum to GABA. In the presence of BDNF, an apparent increase in neurons, all of which extended processes with extensive branching, was observed. Scale bar, $50 \mu \mathrm{m}$. Quantitative analyses $(C)$ showed that BDNF-treated spheres had twice as may neurons, relative to control. Data represent the mean \pm SEM for 125 and 113 spheres in control and BDNF conditions, respectively, examined in at least four independent culture preparations; $* *, p<0.001$. 

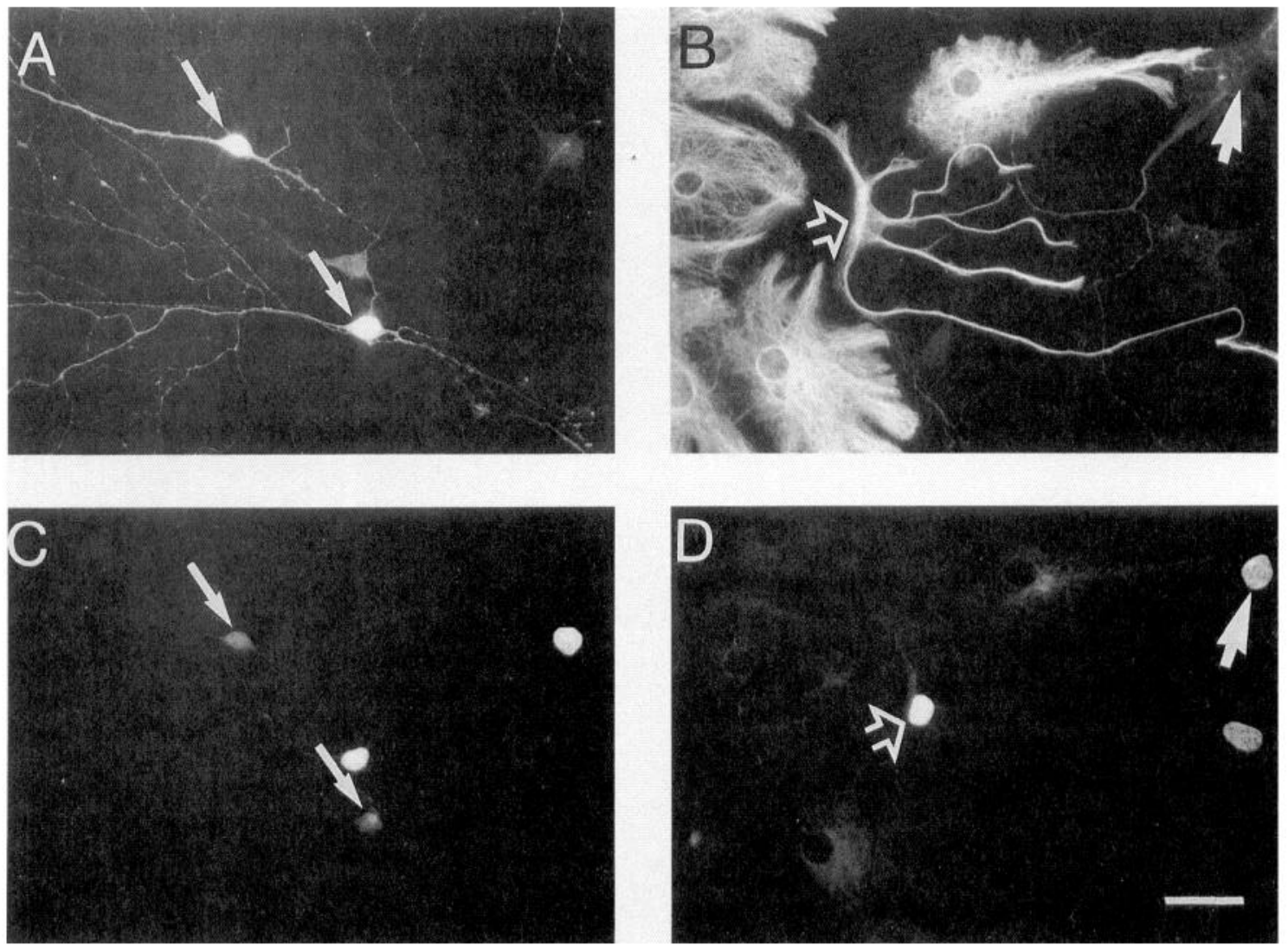

Figure 5. BDNF does not induce the proliferation of EGF-generated neuronal precursors. EGF-generated spheres were rinsed free of EGF and cultured in the presence of $10 \mathrm{ng} / \mathrm{ml}$ of BDNF and $1 \mu \mathrm{M}$ BrdU. Spheres were then fixed and processed for dual label indirect immunocytochemistry for neuronal $(A)$ and glial $(B)$ antigens and $\operatorname{BrdU}(C, D)$. Cells with neuronal morphology and immunoreactivity for NSE $(A$, small, long arrows) did not incorporate BrdU $(C)$. On the other hand, cells expressing GFAP-immunoreactivity $(B$, open arrow) and those that were unreactive $(B$, large arrowhead) incorporated BrdU $(D)$. Similar results were obtained with spheres that were not treated with BDNF (not shown). Scale bar, $30 \mu \mathrm{m}$.

neuronal numbers in BDNF-treated spheres, after 10 DIV (Fig. $4 C$ ). Indirect immunocytochemistry for GFAP or $\mathrm{O} 4$ showed no significant changes in numbers of astrocytes or oligodendrocytes, respectively (data not shown).

\section{$B D N F$ increases in neuronal number are not due to proliferation and do not persist over longer culture periods}

In order to determine whether the increase in neuronal number in spheres exposed to BDNF was due to division of neuronal precursors, spheres were rinsed free of EGF and cultured in media with $1 \%$ FBS and $1 \mu \mathrm{M}$ bromodeoxyuridine (BrdU), in the absence or presence of BDNF. BrdU incorporates into the DNA of dividing cells and has been used by our laboratory as a reliable assay for newly generated neurons (Reynolds and Weiss, 1992; Reynolds et al., 1992; Vescovi et al., 1993). At 10 DIV, dual label indirect immunocytochemistry with antibodies directed against NSE and BrdU revealed that virtually all NSEimmunoreactive cells, arising from either control or BDNF-treated spheres, were not BrdU-immunoreactive (Fig. 5A,C). These results were consistent in three independent culture preparations. This finding suggests that the increase in the numbers of neurons observed in the presence of BDNF was not due to proliferation of neuronal precursors. Although neuronal precursors were not dividing, BrdU incorporated into non-neuronal cells. BrdU incorporation was observed principally in flat cells, of which some were GFAP-immunoreactive, in both control and in BDNF-treated spheres (Fig. 5B,D).

Given that there was a significant increase in the number of neurons in spheres cultured for 10 DIV in the presence of BDNF, and that this increase in neuronal numbers was not due to the proliferation of neural precursors, we next examined the time course of BDNF actions. Preliminary experiments revealed that removal of BDNF $24 \mathrm{hr}$ after plating resulted in spheres that were not different than control spheres when examined at 10 DIV. These early studies also indicated that BDNF was required for at least 5 DIV or more to yield the significant increase in the numbers of neurons that morphologically and antigenically reached maturation by $10 \mathrm{DIV}$. To examine the effect of BDNF over a time period extending beyond 5-10 DIV, EGF-generated spheres were rinsed free of EGF as described above. Four to five spheres of similar size were plated by micromanipulation, onto polyornithine coated glass coverslips in each of the 24 wells of the culture plate (in $1 \mathrm{ml}$ of media containing $1 \%$ FBS). BDNF $(10 \mathrm{ng} / \mathrm{ml})$ was added to 12 of the 24 wells only at plating. At 5, 10, 21, and 27 DIV coverslips were transferred from the culture plate, to another plate containing $4 \%$ paraformaldehyde for fixation and subsequent indirect immunocytochemistry for neuronal antigens. As shown in Figure 6, at 5 DIV there was no significant difference between the numbers of neurons in control versus the BDNF-treated spheres. At 10 DIV, 
Figure 6. BDNF increases in neuronal numbers diminishes over time. EGF-generated spheres were rinsed free of EGF and cultured in the absence or presence of $10 \mathrm{ng} / \mathrm{ml}$ of BDNF. After the indicated days in vitro, spheres were fixed and the numbers of neurons counted. Significant increases in neuronal numbers were observed at 10 and $21 \mathrm{~d}$ in vitro, but not at 5 and $27 \mathrm{~d}$ in vitro. Data represent the mean $\pm \mathrm{SEM}$ for $100-200$ spheres in control and BDNF conditions, examined in at least four independent culture preparations; $* *, p<0.001 ; *, p<0.05$.

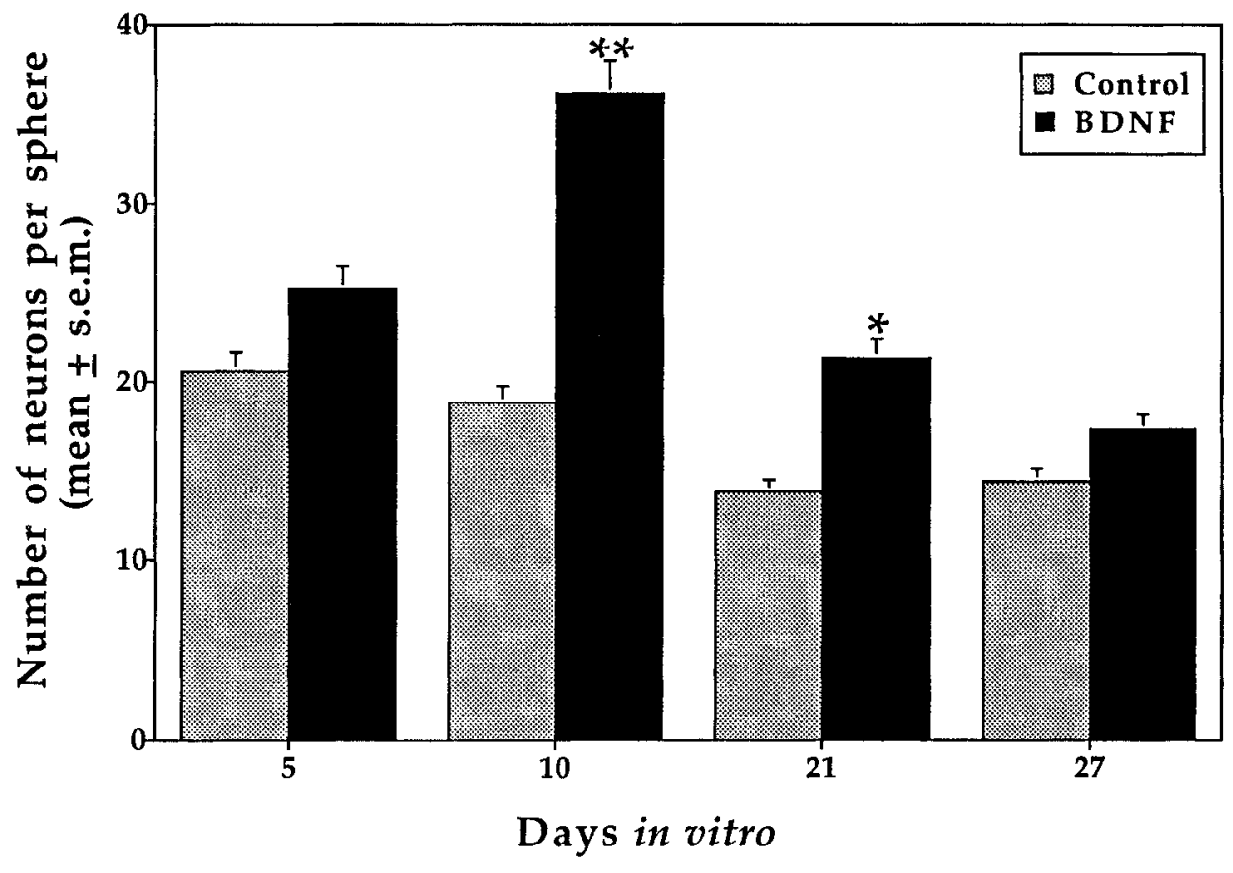

21 DIV only. The different procedures with respect to BDNF administration consisted of (1) control, which did not receive BDNF; (2) one-time addition of BDNF at the beginning of the culture for the duration of $21 \mathrm{DIV}$; (3) exposure to BDNF for $48 \mathrm{hrs}$ only, followed by its removal for the subsequent $19 \mathrm{DIV}$; (4) control for the media change, but which did not receive BDNF; (5) supplementation of BDNF, by adding $5 \mathrm{ng} / \mathrm{ml}$ every second day, throughout $21 \mathrm{DIV}$; (6) single readdition of BDNF at $10 \mathrm{DIV}$; and (7) delayed addition of BDNF at only $10 \mathrm{DIV}$. After 10 and 21 DIV these spheres were processed for immunocytochemistry using antiserum to NSE and a secondary antibody conjugated to alkaline phosphatase (developed with NBT and BCIP). Neurons and their processes were quantified in spheres from five independent culture experiments such that the reader was blind to the experimental procedures. The data obtained (Table 1) was statistically analyzed by $\chi^{2}$ analysis.

\section{Neuron numbers}

In the first procedure (1 in Table 1) spheres were grown in culture media plus $1 \%$ FBS without BDNF, while spheres cultured in the second procedure (2) received $10 \mathrm{ng} / \mathrm{ml} \mathrm{BDNF}$ once only at the time of plating. As with the time course study above, consistency in neuronal numbers was observed at two levels throughout these experiments: one corresponding to time, and the other to treatment with BDNF. As illustrated in Table 1, there were consistently more neurons per sphere at $10 \mathrm{DIV}$, in both control as well as in the presence of BDNF, than there were at 21 DIV $(p<0.01)$. However, there were consistently more neurons counted in BDNF $[72 \%$ more at 10 DIV $(p<0.001)$ and $59 \%$ more at 21 DIV $(p<0.01)]$ relative to control spheres at both time intervals. At 21 DIV, neuronal numbers in control spheres had decreased by $23 \%$ in comparison to a $29 \%$ decrease in the presence of BDNF. Again, these results indicated that over an extended culture period loss of neuronal cells occurred both in the absence and presence of BDNF.

Is continuous BDNF required for increases in neuronal numbers? To determine if the continued presence of BDNF was a requirement for observing the significant increase in the numbers numbers at 10 and 21 DIV. Process outgrowth was quantified at iments glass coverslips were not used). For each experiment,
two culture plates were prepared for quantification of neuronal

four to five spheres of similar size were plated by micro-manipulation directly into polyornithine-coated plastic wells of the culture plate in $1 \mathrm{ml}$ of media containing $1 \%$ FBS (in these experiments glass coverslips were not used). For each experiment

BDNF-treated spheres contained close to twice as many neurons administration of BDNF should result in little or no increased numbers of neurons, when compared to control. The decrease in ence neuronal differentiation. A in neuronal numbers over time could be the result of (1) deplequirement for mature versus immature neurons. To distinguish between the actions of BDNF in promoting survival versus differentiation, a series of experiments were designed in which the numbers of neurons and neurites were quantified in procedures which varied with respect to administration of BDNF. EGF-generated spheres were rinsed free of EGF as described above and tween the numbers of neurons generated from the spheres in the absence or presence of BDNF became less significant. Only 55\%
more neurons were observed in BDNF treated spheres at 21 DIV was observed in BDNF-treated spheres whereas the numbers of neurons counted in control spheres did not change from those
at 21 DIV. The difference between control and BDNF-treated spheres was no longer significant. These findings demonstrate persist over time and that over time a decline in neuronal num-
bers occurs in spheres cultured with or without BDNF. Quantitative analyses of neuron and neurite numbers in varying BDNF administration procedures favor a role for $B D N F$ as a differentiation factor

If BDNF is a survival factor the numbers of neurons observed neuronal numbers by 27 DIV suggests that BDNF is not a surternatively, BDNF could be a survival factor and the decrease tion of BDNF in culture media, or (2) additional survival re- 
Table 1. Effects of various BDNF administration procedures on neuron and neurite numbers

\begin{tabular}{|c|c|c|c|c|}
\hline \multirow[b]{3}{*}{ Procedure } & \multicolumn{4}{|l|}{ Assay } \\
\hline & \multicolumn{3}{|c|}{$\begin{array}{l}\text { Number of neurons } \\
\text { (mean } \pm \text { SEM) }\end{array}$} & \multirow{2}{*}{$\begin{array}{l}\begin{array}{l}\text { Number of } \\
\text { neurites }\end{array} \\
\text { (mean } \pm \text { SEM) } \\
21 \text { DIV }\end{array}$} \\
\hline & $10 \mathrm{DIV}$ & $21 \mathrm{DIV}$ & $\begin{array}{l}\% \text { change } \\
(10 \rightarrow 21 \\
\text { DIV })\end{array}$ & \\
\hline 1. Control & $\begin{array}{l}19.9 \pm 1.5 \\
(100) \\
n=93\end{array}$ & $\begin{array}{l}15.3 \pm 1.3 \\
(100) \\
n=64\end{array}$ & -23 & $\begin{array}{l}64.6 \pm 9.9 \\
(100) \\
n=5\end{array}$ \\
\hline 2. BDNF $(10 \mathrm{ng} / \mathrm{ml})$ at plating & $\begin{array}{l}34.3 \pm 2.8 \\
(172) \\
n=86\end{array}$ & $\begin{array}{l}24.4 \pm 2.1 \\
(159) \\
n=53\end{array}$ & -29 & $\begin{array}{l}239.2 \pm 28.2 \\
(370) \\
n=5\end{array}$ \\
\hline $\begin{array}{l}\text { 3. (a) } \mathrm{BDNF}(10 \mathrm{ng} / \mathrm{ml}) \text { at plating } \\
\text { (b) Change to control media at } \\
48 \mathrm{hr}\end{array}$ & $\begin{array}{l}22.7+1.9 \\
(114) \\
n=90\end{array}$ & $\begin{array}{l}19.4+1.5 \\
(125) \\
n=92\end{array}$ & -15 & $\begin{array}{l}58.0+8.5 \\
(<100) \\
n=5\end{array}$ \\
\hline $\begin{array}{l}\text { 4. (a) Control } \\
\text { (b) Change media at } 48 \mathrm{hr}\end{array}$ & $\begin{array}{l}20.3 \pm 2.4 \\
(101) \\
n=79\end{array}$ & $\begin{array}{l}15.7 \pm 1.5 \\
(103) \\
n=108\end{array}$ & -23 & - \\
\hline $\begin{array}{l}\text { 5. (a) BDNF }(10 \mathrm{ng} / \mathrm{ml}) \text { at plating } \\
\text { (b) BDNF }(5 \mathrm{ng} / \mathrm{ml}) \text { every } 48 \mathrm{hr}\end{array}$ & $\begin{array}{l}33.3 \pm 2.7 \\
(167) \\
n=83\end{array}$ & $\begin{array}{l}21.7 \pm 2.0 \\
(142) \\
n=121\end{array}$ & -35 & $\begin{array}{l}334.6 \pm 48.6 \\
(520) \\
n=5\end{array}$ \\
\hline $\begin{array}{l}\text { 6. (a) BDNF }(10 \mathrm{ng} / \mathrm{ml}) \text { at plating } \\
\text { (b) BDNF }(10 \mathrm{ng} / \mathrm{ml}) \text { at } 10 \mathrm{DIV}\end{array}$ & - & $\begin{array}{l}24.0 \pm 2.0 \\
(157) \\
n=97\end{array}$ & - & $\begin{array}{l}215.0 \pm 33.2 \\
(333) \\
n=5\end{array}$ \\
\hline $\begin{array}{l}\text { 7. (a) Control }- \text { first } 10 \mathrm{DIV} \\
\text { (b) BDNF }(10 \mathrm{ng} / \mathrm{ml}) \text { at } 10 \mathrm{DIV}\end{array}$ & - & $\begin{array}{l}23.7 \pm 2.1 \\
(155) \\
n=103\end{array}$ & - & $\begin{array}{l}166.2 \pm 22.0 \\
(257) \\
n=5\end{array}$ \\
\hline
\end{tabular}

Quantification of neuron and neurite numbers was performed as described in Materials and Methods. The values in parentheses are the calculated percentages relative to control, which was $100 \%$. The $n$ values are the numbers of single spheres analyzed, within a minimum of five independent culture preparations. Statistical comparisons are described in Materials and Methods and Results.

of ncurons at $10 \mathrm{DIV}, \mathrm{BDNF}(10 \mathrm{ng} / \mathrm{ml})$ was added to the culture at the time of plating and removed $48 \mathrm{hr}$ later (procedure 3). $\mathrm{BDNF}$ was removed by aspirating the BDNF-containing media and quickly replacing it with control media. To exclude the possibility that the media change itself was responsible for any differences in neuronal numbers a sister control culture (4) was run for this procedure, in which the media was also removed at 48 hr. When spheres were exposed to BDNF for only $48 \mathrm{hr}$, the number of neurons counted at $10 \mathrm{DIV}$, was not significantly different than that counted in sister control spheres. In comparison, when spheres were allowed to remain in the presence of BDNF, 72\% more neurons were counted with respect to control spheres at $10 \mathrm{DIV}(p<0.001)$. At $21 \mathrm{DIV}$, however, there were $25 \%$ more neurons in spheres that received the $48 \mathrm{hr}$ exposure to BDNF than there were in the control spheres $(p<0.05)$, versus $59 \%$ more neurons in spheres cultured in the presence of $\mathrm{BDNF}(p<0.01)$. It is worth noting that in control spheres run to parallel the removal procedure for BDNF, the number of neurons produced from spheres did not differ from that observed in the control procedure where there was no media change.

Is the decrease in BDNF enhanced neuronal numbers over time due to depletion of the factor? In the next two procedures, the possible depletion of BDNF in the culture media, after its addition at the time of plating, was addressed by supplementing BDNF $(5 \mathrm{ng} / \mathrm{ml}$ ) every $48 \mathrm{hr}$ (procedure 5) or the readdition of BDNF $(10 \mathrm{ng} / \mathrm{ml})$ at $10 \mathrm{DIV}$ (procedure 6). When neurons were quantified at 10 DIV there was no significant difference between spheres that received BDNF only at the time of plating and those that received BDNF every $48 \mathrm{hr}$. Similarly at $21 \mathrm{DIV}$, there was no significant difference between neuronal numbers quantified in spheres receiving BDNF only at the time of plating and those that received BDNF continuously or ones in which BDNF was re-added at $10 \mathrm{DIV}$. Hence a continuous supply of BDNF does not further increase the numbers of neurons produced at $10 \mathrm{DIV}$ nor does it prevent the subsequent loss of neurons over time.

Does delayed BDNF administration have an effect on neuronal numbers? In the last procedure (7) spheres were plated in culture wells in media plus $1 \%$ FBS only. At 10 DIV these spheres received their first exposure to BDNF $(10 \mathrm{ng} / \mathrm{ml})$ and were left undisturbed for another 11 DIV. The following observations were made at 21 DIV: (1) the numbers of neurons was not significantly different from those in spheres where BDNF was added only at the time of plating, or those in which BDNF was supplemented once (10 DIV) or every $48 \mathrm{hrs}$; (2) the number of neurons produced from spheres at 21 DIV, even after delayed addition of BDNF, was significantly greater $(55 \%, p<$ 0.01 ) than neuronal counts obtained from control cultures which never received BDNF and analyzed at $21 \mathrm{DIV}$; and (3) delayed administration of BDNF at 10 DIV (and counts at 21 DIV) showed a small, but significant $(p<0.05)$ increase over the numbers of neurons in control cultures at $10 \mathrm{DIV}$.

These findings indicate that BDNF is continuously required for an action on neuron numbers and that the erosion of BDNF increases over time is not due to depletion of the factor. Delayed 
administration of BDNF is capable of mimicking the increase in numbers due to BDNF being present at plating and throughout the culture period.

\section{Neurite numbers}

In the absence of BDNF (procedure 1), neurons extended processes that possessed a relatively simple outgrowth pattern. An average of $64.6 \pm 9.9$ neurites were counted in these spheres (see Materials and Methods for details of the counting procedure). In the presence of BDNF (procedure 2), however, long processes extended out of ncuronal cell bodies in an intricate and dense network of branches. Process outgrowth in these spheres relative to control was increased by $270 \%(p<0.001)$ : This is clearly greater than that expected as a result of the increase in neuronal numbers which was $72 \%$. When BDNF was removed after $48 \mathrm{hr}$ (procedure 4 ), there was no significant difference in the numbers of neurites counted in this procedure when compared to control spheres. The greatest number of neurites ( $420 \%$ increase over control) was observed in spheres that were supplemented with BDNF every $48 \mathrm{hr}$ (procedure 5). When BDNF was readded (at 10 DIV) to spheres that had received BDNF at the time of plating, the numbers of neurites/ sphere were not significantly different than that observed when BDNF was added at plating. Although fewer neurites were observed in spheres that received a delayed addition of BDNF (procedure 7 ), it was significantly more (157\% increase; $p<$ $0.01)$ than that obscrved in control spheres.

To determine if a continuous supply of BDNF further enhanced process growth, data from procedure 5 was compared to that obtained in procedure 2 . When neurons arising from the spheres received BDNF ( $5 \mathrm{ng} / \mathrm{ml}$ ) every $48 \mathrm{hr}$ there was a $40 \%$ increase $(p<0.01)$ in process outgrowth relative to that observed in spheres receiving BDNF only at the time of plating. However when spheres plated in BDNF receive additional BDNF (10 ng/ml) at 10 DIV no significant difference in neurite outgrowth is observed over those that receive BDNF only at the time of plating. Of note here is that whereas supplementing BDNF continuously (procedure 5) does not produce an increase in the numbers of neurons when compared to those that receive a one-time supplement (procedure 6) delayed addition of BDNF (procedure 7), continuous BDNF does induce a significant increase in neuronal process growth. Although neurite outgrowth was quantified only at $21 \mathrm{DIV}$, in spheres that received BDNF at the time of plating only, a similar density of processes was observed at 10 DIV as well, while in control spheres process outgrowth was minimal (illustrated qualitatively in Fig. $3 A, B$ ).

These results demonstrate that the presence of BDNF promotes neuronal process growth and this action appears to be further enhanced by maintaining a continuous supply of BDNF in the media.

\section{$B D N F$ actions do not involve the enhanced differentiation of a novel neuronal phenotype}

We have previously reported that when EGF-generated spheres are allowed to differentiate, the principal neurotransmitter phe- notypes of newly generated neurons are GABA and substance P (SP) (Reynolds et al., 1992). As outlined in the introduction, examination of BDNF actions on cultures of postmitotic neurons has provided evidence for enhancement of expression of subpopulations of neuronal phenotypes. To determine if the BDNFinduced increase in neuronal numbers was associated with the induction of a novel neurotransmitter phenotype, spheres were rinsed free of EGF and plated in the absence or presence of BDNF (10 ng/ml). At $10 \mathrm{DIV}$, the spheres were fixed and processed for indirect dual label immunocytochemistry with monoclonal antibody directed towards either of the neuronal antigens $\beta$-tubulin or MAP-2 and antisera raised against a variety of neurotransmitters or synthesizing enzymes. The antisera for neurotransmitters or synthesizing enzymes tested included GABA, SP, somatostatin, neuropeptide $\mathrm{Y}, \mathrm{ChAT}$, tyrosine hydroxylase, 5-HT, met-enkephalin, and glutamate. All of these antisera have been used successfully by our lab to identify neuronal populations in primary embryonic mouse CNS cultures. The presence of BDNF did not induce the expression of any new neurotransmitter phenotypes in neuronal cells within the spheres. Cells with neuronal morphology, colocalized GABA (Fig. 7A) and SP (Fig. 7B). In fact, $96 \%$ of all neurons immunoreactive for GABA $(n=316$ neurons) in BDNF-treated cultures, and $87 \%$ of all GABAergic cells in control conditions ( $n=83$ neurons) also exhibited immunoreactivity to SP. The restriction of BDNF actions to this one phenotype was further substantiated by independent quantification of GABA and SP neuronal numbers (Fig. $7 C$ ). In the presence of BDNF there were more $\mathrm{GABA}^{+}$and more $\mathrm{SP}^{+}$neurons than there were in control cultures $(p<0.001)$. The results also indicated no significant difference in the numbers of $\mathrm{GABA}^{+}$and $\mathrm{SP}^{+}$neurons within either the BDNF-treated cultures or the untreated cultures, confirming that the two neurotransmitters were colocalized. From these data, we conclude that the effects of BDNF are not inductive or selective for a particular neurotransmitter phenotype, rather BDNF acts equally upon a single population of EGF-generated neuronal precursors.

\section{Discussion}

The expression of $t r k \mathrm{~B}$ in newly formed structures of the mammalian CNS, as well as in the adult (Klein et al., 1990), supports a role for the principal ligand BDNF in neural development. Of the three neurotrophin receptors examined in this study, only trkB was expressed in appreciable quantities in spheres of undifferentiated cells generated by EGF-responsive stem cells. BDNF directly enhanced the differentiation of neuronal precursors within the spheres, this action being characterized by a transient increase in neuronal numbers and a pronounced action on neurite outgrowth. BDNF did not, however, enhance the long term survival of these same neuronal precursors, regardless of the manner of administration. It is plausible to suggest that BDNF may act subsequent to mitogens such as EGF (Reynolds et al., 1992) and bFGF (Vescovi et al., 1993) in the restriction/ differentiation of newly generated neurons derived from stem

\footnotetext{
Figure 7. BDNF actions are on a single population of neurons that colocalize GABA and substance P. EGF-generated spheres that were rinsed free of FGF and cultured in the absence or presence of $10 \mathrm{ng} / \mathrm{ml}$ of BDNF for $10 \mathrm{DIV}$, were fixed and processed for dual label indirect immunocytochemistry with antibody to GABA $(A)$ and antiserum to substance P $(B)$. Ninety-six percent of GABA-immunoreactive neurons were also immunoreactive for substance $\mathbf{P}(n=316$ neurons). Scale bar, $30 \mu \mathrm{m}$. Quantitative analyses $(C)$ indicated that BDNF treatment resulted in similar, significant augmentation in the numbers of neurons expressing both GABA and substance P. Data represent the mean \pm SEM for 3852 spheres in control and BDNF conditions, examined in at least four independent culture preparations; **, $p<0.001$.
} 

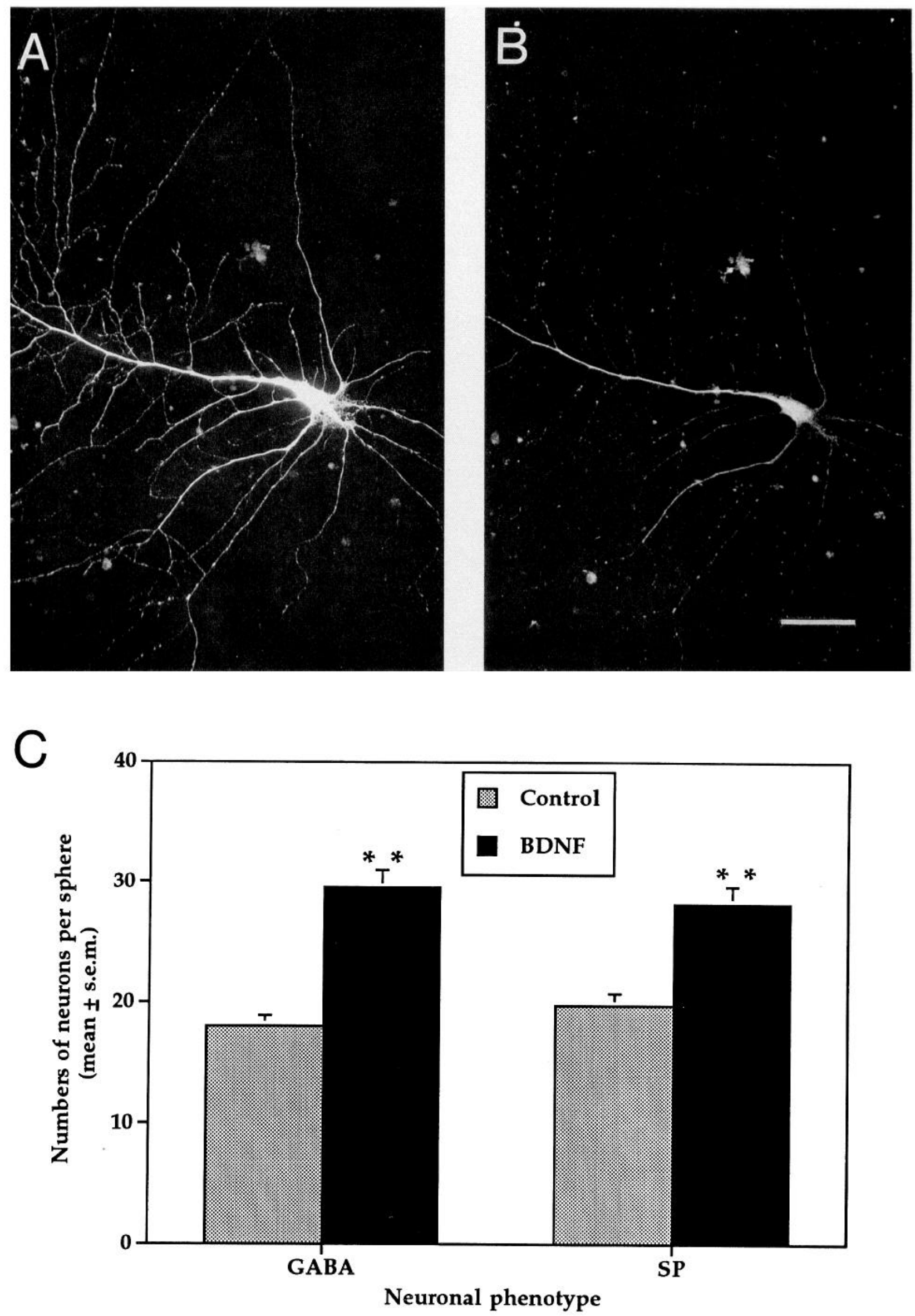
cell precursors. Additional factors are likely required for long term neuronal survival.

In studies of the PNS, neurotrophins have been demonstrated to play roles in the proliferation, differentiation and survival of neuronal precursors (reviewed in Davies, 1994). In contrast, the vast majority of studies of neurotrophin actions in the CNS have focused on postmitotic neuronal populations. Given the expression of $t r k \mathrm{~B}$ in the neuroepithelium as early as E9.5 in the rat (Klein et al., 1990), perhaps it is not surprising that this receptor. is expressed on undifferentiated cells derived from an embryonic neural stem cell. Both the catalytic domain-containing and noncatalytic (truncated) forms of $t r k \mathrm{~B}$ are expressed in the stem cell progeny, however c-fos immunoreactivity studies suggest that the former is restricted to neuronal cells. The location and function of the truncated form in the stem cell progeny remains undetermined. Despite the presence of $t r k \mathrm{~B}$ on the stem cell-derived mitotically active cells, BrdU incorporation studies suggest that the actions of BDNF do not include the stimulation of neuronal precursor cell division. Such activity is consistent with virtually all studics of ncurotrophin actions on dissociated embryonic CNS tissue. NGF has been reported to enhance striatal neuron precursor cell division, however this action required pretreatment with bFGF (Cattaneo and McKay, 1990).

After spheres of undifferentiated cells were exposed to BDNF for 10 DIV, there was a 1.7-2-fold increase in neuronal numbers. This significant increase, however, decreased over time and was not apparent after 27 DIV. This decrease was not due to depletion of BDNF in the medium and thus suggests that BDNF does not enhance long term neuronal survival nor is it capable of preventing a decline in neuronal numbers. In fact, delayed exposure to BDNF was as effective as BDNF administration throughout the culture period in increasing neuronal numbers. Moreover, the delayed administration of BDNF at 10 DIV actually yielded more neurons (although this just achieved statistical significance at 21 DIV) than were present prior to exposure to the factor. In addition, a $48 \mathrm{hr}$ exposure to BDNF is sufficient to induce an increase in neuronal numbers after $21 \mathrm{DIV}$, although not as great as that due to continuous administration. We interpret these results as indicative of an action of BDNF in either enhancing the antigenic differentiation of committed immature neurons or directing the fate of uncommitted precursors with neuronal potential (discussed further below). Although some earlier studies of dissociated embryonic CNS cells concluded that BDNF enhanced neuronal survival (Alderson et al., 1990; Hyman et al., 1991, 1994), some of those conclusions may be reconsidered in light of several issues. More than an issue of semantics and taking into account observations made in our study, the data in those studies could be interpreted as enhancement of neuronal differentiation rather than survival. In those studies, the focus was on septal cholinergic (Alderson et al., 1990) and mesencephalic dopaminergic neurons (Hyman et al., 1991), each of which comprises 1-5\% of the total neuronal population examined. While the total neuronal numbers did not change, BDNF did enhance the numbers of cholinergic (AChEimmunoreactive) and dopaminergic (tyrosine hydroxylase-immunoreactive) neurons by two-to threefold. The authors showed that delayed addition of BDNF resulted in a reduction in neuron numbers and thus argued for a survival role. However, in neither case was the delayed exposure carried out for the same period of time as those exposed without delay. Moreover, the authors did not examine extended periods in culture to determine whether BDNF could enhance these phenotypes over the long term.
In any case, the findings of those studies could have been interpreted as BDNF-induced enhancement or switch of neuronal phenotype, which may only be possible over a narrow window of timc.

Given the results of many other studies (including those examining similar neuronal populations) which clearly demonstrate that BDNF is a differentiation factor, that is, enhancing the neurotransmitter phenotype properties of neurons without affecting neuronal numbers (Knusel et al., 1991; Ip et al., 1993; Mizuno et al., 1994; Nawa et al., 1994), there is little evidence for BDNF as a long term survival factor for CNS neurons. Interestingly, studies of retinal ganglion cells (Johnson et al., 1986; RodriguezTebar et al., 1989) and cerebellar granule neurons (Segal et al., 1992; Lindholm et al., 1993) demonstrate an increase in total cell number in response to BDNF, when measured after 4-7 DIV. Again, while the authors argue that this is indicative of an action on neuronal survival, in both systems long term survival was not measured. Moreover, in both systems the role of BDNF in enhancing neuronal numbers is transient (Rodriguez-Tebar et al., 1989; Segal et al., 1992), whereby the same populations derived from older animals are no longer susceptible to BDNF (actions on process growth in older preparations was not examined). Nevertheless, these findings support a role for BDNF as a commitment/short-term survival factor, whose long term survival is dependent on additional factors and/or other neurotrophins.

In addition to its ability to enhance neurotransmitter phenotype, some of the studies of BDNF actions on CNS neuron populations have included observations of enhanced neurite outgrowth (Alderson et al., 1990; Mizuno et al., 1994). In the present study, we observed a BDNF enhancement of neurite outgrowth that was entirely dependent on the continued presence/ addition of the factor. Several conclusions arise from our quantitative analyses. First, although a $48 \mathrm{hr}$ exposure to BDNF is not sufficient to enhance neuritic growth, administration of the factor at plating is more effective than delayed administration in inducing neuritic outgrowth, suggesting that younger cells are more susceptible to the neurite enhancing effect. Second, repeated addition (every $2 \mathrm{~d}$ ), but not a one time addition at 10 DIV, of BDNF resulted in a significant increase in neurites without any increase in neuronal numbers. The final and perhaps most significant conclusion is that all the actions of BDNF on neurites are independent of neuronal numbers. Interestingly, in the only other quantitative assessment of these phenomena (Lindholm et al., 1993), cerebellar granule cells also exhibited robust neuritic growth independent of neuronal numbers.

An observation made in this study, and apparent in reviewing the literature, is that some neurons will exhibit differentiation/ short-term survival in the absence of BDNF. Although rarely addressed, this observation may serve to further elucidate the precise role that BDNF plays in neuronal development. We propose two explanations for this phenomenon. The first is that there are two populations of neuronal cells, derived from the EGF-responsive stem cell-one that is BDNF-responsive, the second nonresponsive. In fact, we are aware of at least two types of neuronal precursors in the spheres of undifferentiated cells, one a unipotent neuroblast and the other a bipotent neuronal/ astroglial precursor (Vescovi et al., 1993). However, several observations argue against differential susceptibility of neuronal subpopulations. Only one neuronal phenotype, a GABA-SP-colocalizing neuron, emerges consistently from these spheres of undifferentiated cells. In contrast to other studies (Ip et al., 1993; Mizuno et al., 1994), no additional phenotypes emerge as a con- 
sequence of enhanced differentiation. In addition, when assayed by c-fos immunoreactivity or by enhancement of neurite outgrowth, all cells with neuronal morphology and antigenicity appear to respond to BDNF. If the neurons that are present in the absence of BDNF were unresponsive, we would expect that at least half of all neuronal cells in the spheres would show no c-fos or process growth in response to BDNF-however, this is not the case. Thus, we propose that the actions of BDNF on cells within the spheres, with respect to increases in neuronal numbers, is a stage-dependent phenomena. Stage dependency has been proposed as an explanation for transient responsiveness, to BDNF, of cells derived from both the PNS (Buchman and Davies, 1993) and CNS (Rodriguez-Tebar et al., 1989; Knusel et al., 1991; Segal et al., 1992). Thus, once neurons have reached a critical period in their differentiation, BDNF is no longer required or ineffective in regulating their further differentiation/long term survival. In spheres of undifferentiated cells, derived from the EGF-responsive stem cell, it is conceivable that cells that are born first and/or have been exposed to cell-cell or cell-extracellular matrix interaction, commit to the neuronal lineage and undergo initial differentiation, do not require exposure to BDNF to achieve this stage. Alderson et al. (1990) demonstrated that cell density determined the extent of BDNF responsiveness, whereby the actions of BDNF in increasing neuronal numbers was only apparent at densities where cell-cell contact or paracrine growth factor release was minimized. Birthdating of cells during their genesis from the EGF-responsive stem cell could address the issue of whether first born cells are more differentiated and not requiring of BDNF.

Despite ruling out a long term survival role and demonstrating a differentiation role with respect to neurite outgrowth, this study leaves one issue unresolved: what underlies the BDNF-induced increase in neuronal numbers that becomes particularly apparent between 5 and 10 DIV? Our results with BrdU incorporation suggest that this action is not due to the proliferation of neuronal precursors. BDNF may simply act to enhance the expression of antigens characteristic of mature neurons. This may be addressed by examining the expression of proteins, that is, voltage-gated calcium channels, synaptic vesicle proteins, etc., after short term administration of BDNF to young (5-7 DIV) sphere cultures. Increases in some of these proteins prior to the increase in neuronal numbers would confirm such a hypothesis. An alternative explanation might be that BDNF influences the fate of uncommitted precursors, or less likely the trans-differentiation of committed precursors, towards the neuronal lineage. Single cell clonal studies, of undifferentiated cells cultured first in the absence or presence of BDNF with subsequent removal of the factor and the addition of a differentiation medium, would address whether BDNF induces/restricts the fate of uncommitted CNS precursor cells. Such approaches were used to demonstrate that BDNF could direct pluripotent neural crest cells towards the primary sensory neuron lineage (Sieber-Blum, 1991).

In this study, the actions of BDNF on process outgrowth of stem cell-derived neuronal cells persists, although BDNF does not prevent the long term decline in neuronal numbers. Other factors, acting in concert with or in place of BDNF, are presumably required for long term neuronal survival. Tetrodotoxin-sensitive electrical activity has been demonstrated to play an important role in the long term survival of cultured CNS neurons (Lipton, 1986; reviewed in Johnson and Deckworth, 1993). Ghosh and colleagues (1994) found that depolarization acts in conjunction with an autocrine/paracrine action of BDNF to en- hance the survival of cultured cortical neurons. Examination of the dependency of cerebellar granule cells found that BDNF actions in neuronal commitment are followed by a role for NT3 , acting through the $t r k \mathrm{C}$ receptor, in further, long term neuronal differentiation/survival (Segal et al., 1992). We are currently examining the role that BDNF may play in inducing the expression of other trk receptors on the stem cell neuronal progeny. Another phenomenon that may participate in the further differentiation of $t r k \mathrm{~B}$ expressing neuronal cells could be the actions of the other principal agonist of this receptor-NT-4/5. Hyman and coworkers (1994) reported the surprising finding that some of the actions of NT- $4 / 5$, presumably through the same receptor, may be distinct from those of BDNF. Some of these processes may contribute to the final stages of differentiation/long term survival of neurons derived from the EGF-responsive stem cell.

\section{References}

Alderson RF, Altman AL, Barde Y-A, Lindsay RM (1990) Brain-derived neurotrophic factor increases survival and differentiated functions of rat septal cholinergic neurons in culture. Neuron 5:297-306.

Barbacid M (1994) The trk family of neurotrophin receptors. J Neurobiol 25:1386-1403.

Berkemeier LR, Winslow JW, Kaplan DR, Nikolics K, Goeddel DV, Rosenthal AR (1991) Neurotrophin-5: a novel neurotrophic factor that activates trk and trkB. Neuron 7:857-866.

Buchman VL, Davies AM (1993) Different neurotrophins are expressed and act in a developmental sequence to promote the survival of embryonic sensory neurons. Development 118:989-1001.

Cattaneo E, McKay R (1990) Proliferation and differentiation of neuronal stem cells regulated by nerve growth factor Nature 347:762765.

Chao MV (1992) Neurotrophin receptors: a window into neuronal differentiation. Neuron 9:583-593.

Collazo D, Takahashi H, McKay RDG (1992) Cellular targets and trophic functions of neurotrophin-3 in the developing rat hippocampus. Neuron 9:643-656.

Curran T, Morgan JI (1991) Stimulus-transcription coupling in the nervous system: involvement of the inducible proto-oncogenes fos and jun. Annu Rev Neurosci 14:421-451.

Davies AM (1994) The role of neurotrophins in the developing nervous system. J Neurobiol 25:1334-1348.

Davies AM, Thoenen H, Barde Y-A (1986) The response of chick sensory neurons to brain-derived neurotrophic factor. J Neurosci 6:1897-1904.

Frederiksen K, McKay RDG (1988) Proliferation and differentiation of rat neuroepithelial precursor cells in vivo. J Neurosci 8:1144-1151.

Galileo DS, Gray GE, Owens GC, Majors J, Sanes JR (1990) Neurons and glia arise from a common progenitor in chicken optic tectum: demonstration with two retroviruses and cell type-specific antibodies. Proc Natl Acad Sci USA 87:458-462.

Ghosh A, Carnahan J, Greenberg ME (1994) Requirements for BDNF in activity-dependent survival of cortical neurons. Science 263:16181623.

Gotz R, Koster R, Winkler C, Raulf F, Lottspeich F, Schartl M, Thoenen $H$ (1994) Neurotrophin-6 is a new member of the nerve growth factor family. Nature $372: 266-269$.

Greenberg ME, Greene LA, Ziff EB (1985) Nerve growth factor and epidermal growth factor induce rapid transient changes in proto-oncogene transcription in PC12 cells. J Biol Chem 260:14101-14110.

Hallbook F, Ibinez CF, Persson H (1991) Evolutionary studies of the nerve growth factor family reveal a novel member abundantly expressed in Xenopus ovary. Neuron 7:857-866.

Hohn A, Leibrock J, Bailey K, Barde Y-A (1990) Identification and characterization of a novel member of the nerve growth factor, brainderived neurotrophic factor family. Nature 344:339-341.

Hyman C, Hofer M, Barde Y-A, Juhasz M, Yancopoulos GD, Squinto SP, Lindsay RM (1991) BDNF is a neurotrophic factor for dopaminergic neurons of the substantia nigra. Nature 350:350-352.

Hyman C, Juhasz M, Jackson C, Wright P, Ip N, Lindsay RM (1994) Overlapping and distinct actions of the neurotrophins BDNF, NT-3, and NT $-4 / 5$ on cultured dopaminergic and GABAergic neurons of the ventral mesencephalon. J Neurosci 14:335-347. 
Ip NY, Yanping L, Yancopoulos GD, Lindsay RM (1993) Cultured hippocampal neurons show responses to BDNF, NT-3 and NT-4, but not NGF. J Neurosci 13:3394-3405.

Johnson EM, Deckwerth TL (1993). Molecular mechanisms of developmental neuronal death. Annu Rev Neurosci 16:31-46.

Johnson JE, Barde Y-A, Schwab M, Thoenen H (1986) Brain-derived neurotrophic factor supports the survival of cultured rat retinal ganglion cells. J Neurosci 6:3031-3038.

Kilpatrick TJ, Bartlett PF (1993) Cloning and growth of multipotential neural precursors: requirements for proliferation and differentiation. Neuron 10:255-265.

Klein R, Parada LF, Coulter F, Barbacid M (1989) trk B: a novel tyrosine protein kinase receptor expressed during mouse neural development. EMBO J 8:3701-3709.

Klein R, Martin-Zanca D, Barbacid M, Parada LF (1990) Expression of the tyrosine kinase receptor gene $t r k \mathrm{~B}$ is confined to the murine embryonic and adult nervous system. Development 109:845-850.

Klein R, Nanduri V, Jing SZ, Lamballe F, Taplely P, Brayant S, CordonCardo C, Jones KR, Reichardt LF, Barbacid M (1991) The trkB tyrosine protein kinase is a receptor for brain-derived neurotrophic factor and neurotrophin-3. Cell 66:395-403.

Knusel B, Winslow JW, Rosenthal A, Burton LE, Seid DP, Nikolics K, Hefti $F$ (1991) Promotion of central cholinergic and dopaminergic neuron differentiation by brain-derived neurotrophic factor but not neurotrophin-3. Proc Natl Acad Sci USA 88:961-965.

Lee MK, Tuttle JB, Rebhum LI, Cleveland DW, Frankfurter A (1990) The expression and post-Iranslational modification of neuron-specific $\beta$-tubulin isotype during chick development. Cell Motil Cytoskel 17: $118-132$.

Leibrock J, Lottspeich F, Hohn A, Hofer M, Hengerer B, Masiakowski P, Thoenen H, Barde Y-A (1989) Molecular cloning and expression of brain-derived neurotrophic factor. Nature 341:149-152.

Lindholm D, Dechant G, Heisenberg C-P, Thoenen H (1993) Brainderived neurotrophic factor is a survival factor for cultured rat cerebellar granule neurons and protects them against glutamate-induced neurotoxicity. Eur J Neurosci 5:1455-1464.

Lindsay RM, Rohrer H (1985) Placodal sensory neurons in culture: nodose ganglion neurons are unresponsive to NGF, lack NGF receptors but are supported by a liver-derived neurotrophic factor. Dev Biol $112: 30-48$

Lindsay RM, Thoenen H, Barde Y-A (1985) Placode and neural crestderived sensory neurons are responsive at early developmental stages to brain-derived neurotrophic factor. Dev Biol 112:319-328.

Lipton SA (1986) Blockade of electrical activity promotes death of mammalian retinal ganglion cells in culture. Proc Natl Acad Sci USA 83:9774-9778.

Maisonpierre PC, Belluscio L, Squinto S, Ip NY, Furth ME, Lindsay RM, Yancopoulos GD (1990) Neurotrophin-3: a neurotrophic factor related to NGF and BDNF. Science 247:1446-1451.

Mizuno K, Carnahan J, Nawa H (1994) Brain derived neurotrophic factor promotes differentiation of striatal GABAergic neurorts. Dev Biol 165:243-256.

Morshead CM, Reynolds BA, Craig CG, McBurney MW, Staines WA,
Morassutti D, Weiss S, van der Kooy D (1994) Neural stem cells in the adult mammalian forebrain: a relatively quiescent subpopulation of subependymal cells. Neuron 13:1071-1082.

Nawa H, Bessho Y, Carnahan J, Nakanishi S, Mizuno K (1994) Regulation of peptide expression in cultured cortical neurons by BDNF. Dev Biol 165:243-256.

Raff MC (1989) Glial cell diversification in the rat optic nerve. Science 243:1450-1455.

Reynolds BA, Weiss S (1992) Generation of neurons and astrocytes from isolated cells of the adult mammalian central nervous system. Science 255:1707-1710.

Reynolds BA, Tetzlaff W, Weiss S (1992) A multipotent EGF- responsive striatal embryonic progenitor cell produces ncurons and astrocytes. J Neurosci 12:4565-4574.

Rodriguez-Tebar A, Jefrey PL, Thoenen H, Barde Y-A (1989) The survival of chick retinal ganglion cells in response to brain-derived neurotrophic factor depends on their embryonic age. Dev Biol 136: 296-303.

Segal RA, Takahashi H, McKay RDG (1992) Changes in neurotrophin responsiveness during the development of cerebellar granule neurons. Neuron 9:1041-1052.

Sheng M, Greenberg ME (1990) The regulation and function of $\mathrm{c}$-fos and other immediate early genes in the nervous system. Neuron $4: 477-485$.

Sieber-Blum M (1991) Role of neurotrophic factors BDNF and NGF in the commitment of pluripotent neural crest cells. Neuron 6:949955.

Soppet D, Escandon E, Maragos J, Middlemas DS, Reid SW, Blair J, Burton LE, Stanton BR, Kaplan DR, Hunter T, Nikolics K, Parada LF (1991) The neurotrophic factors brain-derived neurotrophic factor and neurotrophin-3 are ligands for the $t r k \mathrm{~B}$ tyrosine kinase receptor. Cell 65:895-903.

Squinto SP, Stitt TN, Aldrich TH, Davis S, Bianco SM, Radziejewski C, Glass DJ, Masiakowski P, Furth ME, Valenzuela DM, DiStefano PS, Yancopoulos GD (1991) trkB encodes a functional receptor for BDNF and NT-3 but not NGF. Cell 65:885-893.

Temple S (1989) Division and differentiation of isolated CNS blast cells in microculture. Nature 340:471-473.

Turner DK, Cepko CL (1987) A common progenitor for neurons and glia persists in rat retina late in development. Nature 328:131-136.

Ventimiglia R, Mather P, Jones BE, Lindsay RM (1993) The neurotrophins BDNF, NT-3 and NT-4/5 promote survival and biochemical and morphological differentiation of striatal neurons in vitro. Soc Neurosci Abstr 19:278.6.

Vescovi A, Reynolds BA, Fraser DD, Weiss S (1993) Basic fibroblast growth factor regulates the proliferative fate of both unipotent (neuronal and bipotent (neuronal/astroglial) epidermal growth factor-generated progenitor cells. Neuron 11:951-966.

Williams BP, Read J, Price J (1991) The generation of neurons and oligodendrocytes from a common precursor cell. Neuron 7:685-693.

Wong V, Arriaga R, Ip NY, Lindsay RM (1993) The neurotrophins BDNF, NT-3, and NT-4/5, but not NGF, upregulate the cholinergic phenotype of developing motor neurons. Eur J Neurosci 5:466-474. 